\title{
A FILOZÓFIA MINT TÁRSADALMI KOMMUNIKÁCIÓS JELENSÉG
}

\section{PHILOSOPHY AS A SOCIAL COMMUNICATION PHENOMENON}

\author{
Fábri György \\ kandidátus, PhD, habilitált egyetemi docens \\ Eötvös Loránd Tudományegyetem Pedagógiai és Pszichológiai Kar \\ gyorgy.fabri@ppk.elte.hu
}

\begin{abstract}
ÖSSZEFOGLALÁS
A filozófia magyarországi társadalmi képe összességében pozitív, bár a mindenkori politikai hatalom az elmúlt negyedszázadban hajlamos volt irritáló tényezőként kezelni. Az ideológiai és identitásviták újraerősödése idején fontossága és közvetlen társadalmi hatása is elfogadottá válik. Még inkább nagy hangsúlyt kap a tényeken és igazságon túli világfelfogás terjedése idején, ami egyre győztesebb trendnek tűnik. Ezt értelmezendő az előadás a tudományos gondolkodás társadalmi kommunikációs vizsgálatában a szociális reprezentáció megközelítését használja. Bemutatja, hogy a tudományos relativizmus, szociálkonstruktivizmus eredetileg baloldali ihletésű programja miképpen ágyazott meg a jobboldali-populista post-truth hullámnak. Ezzel szemben a tudományos realizmus újragondolását javasolja a filozófia tanításaként, és lehetségesnek tartja a személyes segítés klasszikusan filozófiai programjának felelevenítését.
\end{abstract}

\section{ABSTRACT}

Philosophy gained a positive social image in Hungary, although politics regularly treated it as an irritation. Importance and direct social impact of the philosophical works are also accepted during the renewing of ideological and identity disputes. Its importance is even more emphasized while perceptions beyond the facts and the truth-based world are spreading, and seem to be a increasingly victorious trend. This study interprets this situation in the frame of social communication of scientific thinking using the approach of social representation. It shows how the originally left-inspired program of scientific relativism, social constructivism has laid the foundation for the right-wing populist post-truth wave. On the other hand, it suggests reconsidering scientific realism as a philosophical teaching and considers it possible to revive the classically philosophical program of personal aid.

Kulcsszavak: társadalmi kommunikáció, realizmus, szociálkonstruktivizmus, post-truth

Keywords: social communication, realism, socialconstructivism, post-truth 
A fillozófusoknak kezdetektől fogva gondjuk van azzal, mit gondol róluk a „,közönség”, a „nép”, az „egyszerü ember”, a ,laikusok”. Remekbe szabott breviáriumokat lehet a témából összeállítani - nagy valószínüséggel ez már meg is történt. Egy ilyen kiadvány bizonyára tükrözi a filozófiatörténeti tanulmányainkból ismerős motívumot, miszerint Platóntól Hegelig szinte egyöntetű ez a rossz érzés, legfeljebb a nagy szecessziósok s hatékonyan szublimálók öntörvényü habitussal reagáltak erre. Mindez az elmúlt kétszáz év szakfilozófiai vagy megértésközpontú irányzataiban még kifinomultabban folytatódott.

Persze, az ilyen idézetgyüjteményböl ugyanakkor az is kitünne, hogy ezt a rossz érzésüket a filozófusok gyakran hajlamosak úgy megfogalmazni, miszerint nem is saját tanításuk értetlen recepciójáról van szó, hanem a filozófiáról magáról is ilyen a közvélekedés. Pszichologizálásnak se volna közepesnél érdekesebb, ha azt firtatnánk, vajon miért is fontos ez a referencia a filozófiát müvelőknek, és - higgyünk nekik - a filozófiának. Referátumomban ehelyett arra teszek kísérletet, hogy a másik oldalról, a közgondolkodásban jelen lévő filozófiakép egyes vonatkozásainak tanulságairól fogalmazzak meg felvetéseket. A filozófia korunkbeli hazai és angolszász társadalmi percepciójának néhány megragadható elemét bemutatva szeretnék ahhoz a nagy hagyományú, de a sok kiábrándító tapasztalat hatására mostanra ódivatúvá és szinte már kínosan nagyigényüvé vált kérdéshez eljutni, hogy mi lehetne a dolga a mostani, nagyon is konkrét eszmetörténeti és társadalmi-értelmiségi helyzetben a filozófiának - vagyis, hogy mire taníthat a filozófia ma?

Az, hogy az ilyesféle kérdésektől távol tartja magát a szakfilozófiák müvelőinek döntő többsége, teljesen érthető a társadalmi fogadtatás oldaláról. A háttérben persze felsejlik a kultúrtörténet seregnyi anekdotája vagy éppen közvetlen negatív eseménye az állítólag (időnként pedig ténylegesen) életidegenné, önmagába zárkózóvá, szócséplésekbe merülővé váló filozofálásról, nem is szólva a társadalomra, köznyugalomra, a fiatalok nevelésére veszélyes filozófiai kellemetlenkedésekről. De nem kell Szókratész bürökpoharáig, a Leo Strauss által elemzett „sorok között” író üldözöttekhez vagy a totalitariánus rendszerek elnyomott/lázadó filozófusaihoz (lásd a Petőfi Kör 56-os filozófusvitáját vagy a hetvenes évek magyar „filozófusperét”) visszamennünk, saját, helyenként nyomasztó élményeink is lehetnek arról, hogy a társadalmi kommunikációban milyen képet alakíthat ki a filozófusokról a napi politikai érdek. Alig két évtizede még napi bornírtságnak tünt, ahogyan az akkor regnáló szocialista miniszterelnök a filozófusok számát sokallta, hat évvel ezelőtt viszont már sajátos vegyülékét tapasztalhattuk meg az ideológiai szembenállással és az utóbb hivatalosan is megalapozatlannak bizonyult büntetőeljárásokkal pozicionált ,ártalmas filozófusok” tételének.

De vajon a politikán túli társadalmi percepció hol jelöli ki a filozófia helyét? Az adatokkal rekonstruálható tényezők között a filozófia iránti elmélyült érdeklödést mutatják a továbbtanulási tendenciák. E tekintetben az elmúlt hat-hét év 
nem hozott döntő változásokat, a filozófiai mesterképzésben továbbtanulni vágyók hetven-nyolcvanan vannak, ami az ún. „kis bölcsészszakok” között nem kirívóan alacsony vagy magas szám (Fábri, 2017). Mindez mutatja, hogy a világszerte domináns bölcsészetellenes tudomány- és felsőoktatás-politikák, illetve frazeológiák közepette is megmaradt a diszciplínának a fiatalokra gyakorolt vonzereje. Mint ahogyan megmaradtak a könyvesboltok filozófiai polcai is - bár az külön elemzendő volna, hogy a magyar olvasóközönség számára mit kínálnak ezek a polcok filozófiaként. Az azonban biztató, hogy az ezoterikus fachok és a „hogyan legyünk boldogok gyorsan/könnyen + szépek is” jellegü irodalom még más, bár egyre bővülö polcokon található.

Közvetlenebb rákérdezésünk egy 2004-es kutatásunkban is mér egyfajta attitüdöt. A filozófia a közvéleményben a tudományosság mércéjén a humán területek között nem szerepel rosszul, amit, mivel a „tudományos” jelleg a válaszadóknál a pozitiv, hasznos, fontos asszociációs körbe tartozott, jó társadalmi kommunikációs helyzetnek tekinthetünk (Fábri, 2004). Az ettől még nyilvánvalóan viták és ellenérzések tárgya, hogy vajon a filozófia képes-e a társadalmi kommunikációra, vagyis az érthetősége mennyire lehet követelmény. És ez nem csupán a laikusok kívülről jövő értetlenkedése. A hatvanas évek pozitivizmusvitájában Karl Popper egyebek között azt kérte számon Jürgen Habermas írásain, hogy a közpénzen tanult és közpénzen dolgozó filozófusoknak kötelességük a „köz” számára érthető nyelven beszélni (Popper, 1993).

A filozófia társadalmi jelenléte mindezen akadályok közepette is virulens, különösen, ha a szociális percepció felfogásában tekintjük. Serge Moscovici eredetileg a pszichológia esetére alkalmazott kutatásai nyomán (Moscovici-Duveen, 2000) elmondható, hogy a filozófiai gondolkodás fogalmai még mélyebben rögzültek a közgondolkodásban, s ott részei a világértelmezéseknek, a valóság megragadásának. Márpedig a két és fél évezredes jelenlét okán ez egy stabil bázis az új ismeretek lehorgonyzásához (anchoring), tehát nagyon nem mindegy, milyen a filozófia pozíciója ebben. Ennek a funkciónak a hatása különösen akkor válik téttel bíróvá, ha a világnézetek egyszerre csak instabillá vagy éppen centrálissá válnak.

Ilyesmi történik manapság is: az ideológiák korának letűntét állító kilencvenes évek után meglepő erővel és mértékben váltak ideologikussá a társadalmi törekvések, konfliktusok, érdekérvényesítések. A sokat emlegetett identitáspolitikák, az etnikai-vallási konfliktusok vagy a rendszerkritikák önmagukban is érdekes jelenségei a filozófiai jellegủ megalapozási igények sokasodásának, de talán még mélyebben érintheti a filozófia társadalmi kommunikációban betöltött szerepét a technológiai váltások reflexiójának igénye - bár ma még nem érzékelni a közgondolkodásban a Karl Marxnál kibontakozott technológiai determinizmushoz vagy Martin Heidegger technológiakritikájához (Smith-Marx, 1994) mérhetö áramlatok jelenlétét. Sokkal inkább a „New Age”, az ezotéria tünik mindinkább 
terjedő interpretációnak a közvélekedésben - nem függetlenül a filozófia egyik legnagyobb hatású huszadik századi vállalkozásának hatásától.

A tudományfilozófia relativista áramlataira gondolok, amelyek a tudományos módszer és önkép helyénvaló felülvizsgálatának során hivatkozásul szolgáltak a tudományos világkép, illetve az azon alapuló, tényalapú (factual based) társadalmi kommunikáció számára. Ennek a megrendülése mindennapjaink élménye, ahogyan az elmúlt években az a - talán kényelmetlen - belátás is hangot kapott, hogy a nyugati világ szabadságelvü és a józanész-használatot evidenciának tekintő berendezkedését fenyegető igazságon túli (post-truth) kommunikációs-politikai-közösségi állapot részint ezekhez az áramlatokhoz köthető (erre már maga Bruno Latour is önkritikusan reflektált: Vrieze, 2017).

Már a nyolcvanas években Alan Bloom a klasszikus bölcsészeti hagyomány feladását azonosította az ,amerikai gondolkodás bezáródásának” egyik fö okaként - együtt a generális mércék, beleértve nemcsak a morális, hanem az igazságmércék feladásával (Bloom, 1987). Alig három évtized kellett hozzá, és Lee McIntyre már az emberi gondolkodás determináltságát firtatja az igazság tiszteletére, megállapítva, hogy ha nem is tudunk ilyen ,huzalozottságot” rekonstruálni, evolúciós szempontból nagyon is egyértelmü a tényeken megmért igazságra orientálódó gondolkodás dominanciája (McIntyre, 2015). Ehhez képest a természettudományos gondolkodást is kontextualizálni, relativizálni igyekvő filozófiai áramlatok elfordulása az objektív igazság létének és megismerhetőségének elfogadásától legfeljebb gondolati játékként áll meg, veszélyei pedig közvetlenek. Amikor tehát a szociálkonstruktivizmus túlmegy a világértelmezések ideológia-kritikáján, és még a természettudomány kapcsán is azt jelenti ki, hogy a férfihatalom eszköze (Sandra Harding, az ismert feminista szerint tudományosnak lenni a nőktől elvárt attitüdökkel szemben az érzéketlenség és pártatlanság normáinak hangoztatását jelenti, sőt, Isaac Newton Principia Mathematicája a nemi erőszak kézikönyve), akkor a tudomány tartóoszlopait gyengíti az összevissza beszéddel szemben (Harding, 1987).

Még célzottabban egyértelmúsíti a társadalmi kommunikációban uralkodóvá vált, igazságon túli érvelések gondolati forrását Kurt Anderson nemrég megjelent könyve, a Fantasyland: How America Went Haywire. Ö a mai posztmodern relativizmus és szociálkonstruktivizmus térnyerését az ún. hatvannyolcas (leginkább baloldali) szellemi irányzatok és mozgalmak egyenes ági folytatásának tartja (Andersen, 2017). Ha elfogadjuk ezt az interpretációt (jómagam hajlok rá), akkor a Hegel megénekelte ,ész cselére” hajazva az ,ész bosszújáról” is beszélhetünk: miközben a „,haladó értelmiség” köreiben a nyitott, liberális gondolkodás győzelmeként volt szokás ünnepelni a relativista, a tudományos gondolkodás béklyóit és elnyomását levető felfogásokat, mostanra ezek logikájának (avagy logikátlanságának) érvényesülése a liberális demokrácia normáit minimum fellazította, a (szélső)jobboldali populizmust pedig a tényrezisztencia és tudományellenség magabiztos politikai és kommunikációs pozíciójába hozta. 
A politikai publicisztikában és a közgondolkodás komolyabb fórumain is mindennapos téma, hogy ezt az állapotot miképpen lehet visszafordítani. A filozófia szempontjából azonban ez a társadalmi kommunikációs kihívás mélyebb problémát vet fel: vajon az észhasználat és a tudományos gondolkodás logikáját, peremfeltételeit érintő, komoly filozófiai kritikák belátásainak megtartásával együtt is vannak-e érvei a filozófiának az igazság nem relativizáló felfogása, a (tudományos) gondolkodás autonómiája mellett? Wilfrid Sellars, Hilary Putmann, Ian Hacking és a többiek más-más utakon és elszánásokkal, de példákat kínálnak erre (Beebee-Dodd, 2005).

Ez a fajta társadalmi kommunikációs szerep nem új és nem kevésbé reményteljes, mint gyakran a múltban volt. A közösségi média vagy a tömegmédia platformja persze nem belakott hely a bölcseleti kifejtések számára - de kommunikációban lenni, vagyis a közösség részének lenni ettöl még most sem eleve feladott törekvése a filozófiának. Különösen nem az a reáltudományok, a technológiai fejlesztések korábban említett, nagyon is stimuláló változásai közepette, amikor a társadalmi kommunikációba közvetlen „megrendeléssel” hívja be a közgondolkodás a filozófiát: értelmezést, helyenként értelmet adni a géntechnológia, az agykutatás, a mesterséges intelligencia, a robotika és a többi reáltudományos fejlemény mindennapjainkat átszövő realitásának (például: Bennett et al., 2009; vagy technológiai oldalról: Pierson, 2017). De ugyanilyen „meghívás” az a kitüntetetten filozófiai reflexiós terület, amely az újraformálódó kulturális, vallási vagy éppen vallástalansági, etnikai/állami identitások morális és közösségi vonatkozásainak értelmezését, bensővé tevését motiválja (Pinker, 2018).

Minderre jó lehetőséget kínál Magyarországon a közoktatásban kötelezővé tett, választható hit- és erkölcstan, illetve etikaoktatás. A bevezetés és szabályozás polgári, oktatási vagy akár egyházi szempontból való problematikusságára, anomáliáira itt nincs mód kitérni, de látva a társadalom preferenciáit, érdemes a lehetőség oldaláról megragadni a helyzetet: a filozófia egyik fó ága, a gyakorlati filozófia, az etika a társadalmi kommunikáció mindennapjainak a része lett. Ezzel a lehetőséggel a magyar oktatási viszonyok, a pedagógusok beszorítottságai közepette nem könnyü persze élni, de legalább létezik egy ilyen csatorna, ahol a filozófia megjelenhet a társadalmi kommunikációban. A filozófus szakmán is múlik, milyen hatékonysággal teszi ezt, és a filozófus szakmai felelőssége is, hogy milyen hatásai lesznek ennek a tantárgynak.

És talán még visszatérhetünk ahhoz a „szolgáltatáshoz” is, amely az USA-ban néhány évtizede már hivatásszerúen is megjelent (ellentmondásosságairól lásd Duane, 2004). Ezt Platón idején a szofisták még igen sikeres piaci szereplőként üzték, majd különféle formákban (udvari filozófusok, szalonok filozófus sztárjai, enciklopédisták, királynők levelező társai) sokáig fennmaradt, hogy a 19. századi akadémiai filozófia elkényelmesedése mellett aztán Sigmund Freud és követői átvegyék a pszichológia (és napjainkra végképp felületessé technicizálva más, 
coaching-szerü formák) számára: a személyes életben szempontokat, tanácsokat, kommunikációképes beszélgetőtársat kínálni.

Tudományértelmezőként, közösségi szereplőként, személyes megszólítóként tehát a filozófia társadalmi kommunikációs szereplő maradhat, és újult erôvel, nagy reményekkel taníthat a hagyomány, a tények, a módszeres gondolkodás tiszteletére, a kritikai gondolkodásra, a tartalmas intellektuális izgalom élvezetére - ma is és holnap is.

\section{IRODALOM}

Andersen, K. (2017): Fantasyland: How America Went Haywire. New York: Random House

Beebee, H. - Dodd, J. (eds.) (2005): Truthmakers: The Contemporary Debate. Oxford: Clarendon Press

Bennett, M. - Dennett, D. - Hacker, P. et al. (2009): Neuroscience and Philosophy. Brain, Mind, and Language. New York: Columbia University Press

Bloom, A. (1987): The Closing of the American Mind. New York: Simon \& Schuster

Duane, D. (2004): The Socratic Shrink. The New York Times, 21 March. https://www.nytimes. com/2004/03/21/magazine/the-socratic-shrink.html

Fábri Gy. (2004): Tudomány, közvélemény, média. Magyar Tudomány, IL, 11, 1252-1268. http:// www.matud.iif.hu/04nov/10.html

Fábri Gy. (2007): A két kultúra és a harmadik. Magyar Tudomány, 167, 2, 183-189. http://www. matud.iif.hu/07feb/10.html

Fábri Gy. (2017): Az egyetem értéke. Budapest: Eötvös Kiadó

Harding, S. (1987): The Science Question in Feminism. Cornell University Press

McIntyre, L. (2015): Respecting Truth. New York-London: Routledge

Moscovici, S. - Duveen, G. (2000). Social Representations: Studies in Social Psychology. Cambridge: Polity Press

Pierson, E. (2017): Hey, Computer Scientists! Stop Hating on the Humanities. Wired, 24. April. https://www.wired.com/2017/04/hey-computer-scientists-stop-hating-humanities/

Pinker, S. (2018): Enlightenment Now: The Case for Reason. Science, Humanism, and Progress. Allen Lane-Viking

Popper, K. R. (1993): Die Logik der Sozialwissenschaften. In: Adorno, T. W. - Dahrendorf, R. - Pilot, H. et al. (1969/1993): Der Positivismusstreit in der deutschen Soziologie. München: Deutscher Taschenbuch Verlag, 103-123.

Smith, M. R. - Marx, L. (eds.) (1994): Does Technology Drive History? The Dilemma of Technological Determinism. Cambridge: MIT Press

Vrieze, J. de (2017): Bruno Latour, a Veteran of the 'Science Wars,' Has a New Mission. Science, 10. Oct. https://www.sciencemag.org/news/2017/10/bruno-latour-veteran-science-wars-hasnew-mission 